\title{
COMO AUMENTAR O FATOR DE IMPACTO NAS BASES WEB OF SCIENCE (WOS) E SCOPUS (SCIMAGO): \\ Ações implementadas pelo Journal of Venomous Animals and Toxins including \\ Tropical Diseases
}

\author{
Juliana Siani Simionato \\ Universidade Estadual Paulista \\ juliana@cevap.unesp.br \\ Selma de Lourdes Pires Martins \\ Universidade Estadual Paulista \\ selma@cevap.unesp.br \\ Jean-Philippe Chippaux \\ Institut de Recherche pour le Développement \\ editorial@jvat.org.br \\ Maria Elena de Lima \\ Universidade Federal de Minas Gerais \\ editorial@jvat.org.br \\ Lucilene Delazari dos Santos \\ Universidade Estadual Paulista \\ lucilenebio@gmail.com \\ Rui Seabra Ferreira Junior \\ Universidade Estadual Paulista \\ rui.ead@gmail.com \\ Benedito Barraviera \\ Universidade Estadual Paulista \\ bbviera@gnosis.com.br
}

\begin{abstract}
Resumo
O Journal of Venomous Animals and Toxins including Tropical Diseases (JVATiTD) foi indexado nas bases Web of Science (WoS) e Scopus (Scimago) em 2006. Entre 2007 e 2012, o Fator de Impacto (FI) estabilizouse entre 0.30 e 0.55. Para aumentá-lo, em 2013 estabeleceu-se parceria com a BioMed Central Springer Nature e uma série de ações foram propostas e implementadas com vistas a alcançar o patamar de $2.0 \mathrm{em}$ cinco anos. As ações foram as seguintes: publicar em fluxo contínuo, buscar novos indexadores estratégicos, reavaliar o corpo editorial, priorizar conteúdos de qualidade, cortar supérfluos, estimular publicação em multimídia, manter um banco de dados atualizado, e publicar séries temáticas e especiais. Para os editores associados foram feitas as seguintes sugestões: participar em eventos da área e em grupos consolidados de pesquisa, além de dar parecer científico para outras revistas. É possível concluir previamente que a nova parceria foi estratégica, pois em 2017 atingiu-se impacto de citações acima de 1.0 tanto no Web of Science (WoS), quanto no Scopus (Scimago). Isso certamente deverá atrair a submissão de bons manuscritos, aumentar o prestígio, a visibilidade mundial e o aumento do número de citações. Como consequência direta, o FI deverá aumentar nos anos vindouros.
\end{abstract}

Palavras-chave'

Fator de Impacto. Web of Science. Scopus. Publicação científica.

\section{INTRODUÇÃO}

A indexação do Journal of Venomous Animals and Toxins including Tropical Diseases
(JVATiTD) na base Web of Science (WoS) ocorreu em 2006. A partir de 2007 foram divulgados anualmente pelo Journal Citation Reports (JCR) os respectivos Fatores de 
Impacto (FI) cujos valores variaram entre 0,30 e 0,55 (Figura 1).

Figura 1. Evolução do fator de impacto na WoS (JCR) entre 2007 e 2012.

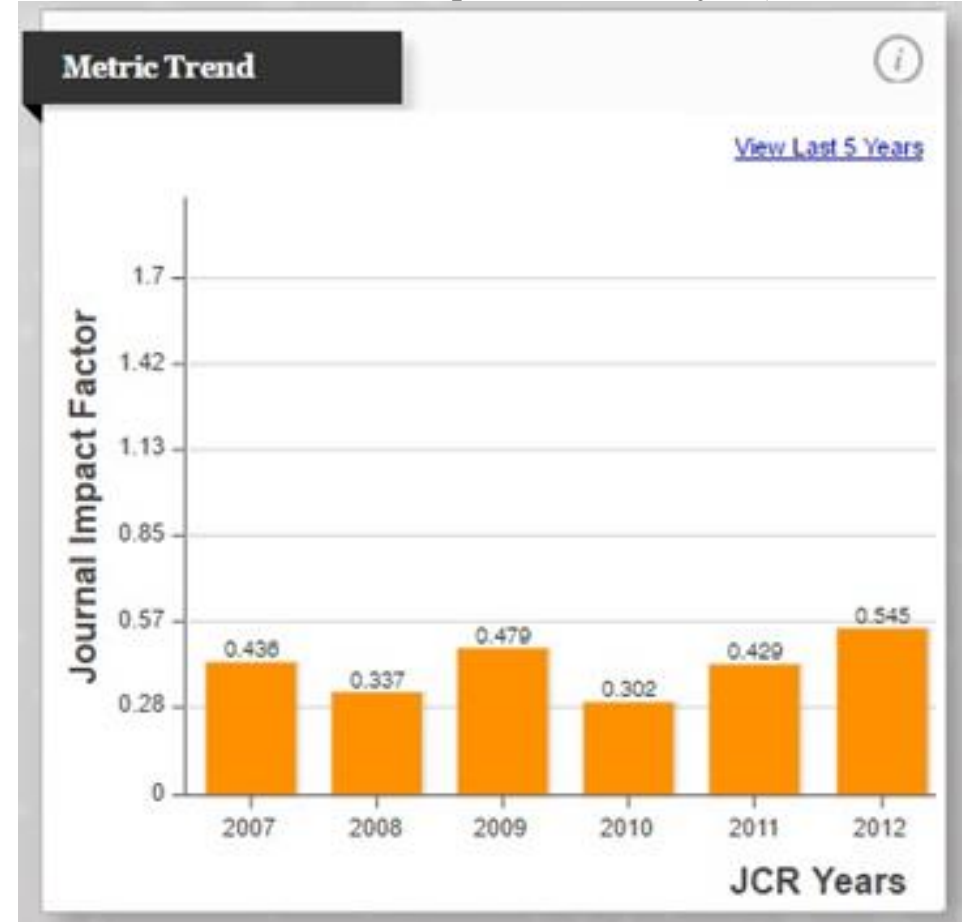

Fonte: Journal Citation Reports, (2012)

Em 2012, em decorrência da estabilização do FI, o conselho editorial do JVATiTD decidiu buscar um parceiro internacional que mantivesse o acesso aberto e gratuito e que contribuísse na melhoria do periódico, inclusive conquistando-se novos indexadores. Optou-se pela BioMed Central Springer-Nature, que se comprometeu a colaborar nessas ações. No início de 2013, esta parceria se consolidou e estabeleceramse metas e ações para os próximos cinco anos tendo por objetivo final alcançar o FI de 2,0 em cinco anos.

\section{AÇÕES IMPLEMENTADAS}

Ao todo foram investidas 12 ações conjuntas com vistas ao aumento do FI da JVATiTD, as quais estão listadas e detalhadas a seguir.

\subsection{Publicar em fluxo contínuo}

Até 2012, o periódico era fasciculado e de periodicidade trimestral (1-3). Apesar de ser uma publicação eletrônica, seguia-se ainda o tradicional formato de citação impressa. De acordo com o International Committee of Medical Journal Editors (ICMJE), os artigos eram citados da seguinte maneira: nome abreviado do periódico, ano, volume, fascículo, páginas. Em 2013, foi implantada a publicação em fluxo contínuo.

A partir de então, a citação passou a ser da seguinte forma: nome abreviado do periódico, ano, volume e número do artigo publicado no ano. Deve ser salientado que todos os artigos publicados pelo JVATiTD desde 1995 possuem Digital Object Identifier (DOI) e estão depositados na base Scientific Electronic Library Online (SciELO), o que facilita a busca na internet e nas bases de dados. Além disso, dentro dessa nova política editorial, artigo finalizado é artigo publicado. Isso aumentou a velocidade da publicação.

\subsection{Buscar indexadores estratégicos}

Embora o JVATiTD fosse indexado na base SciELO desde 1998, e nas bases WoS 
e Scopus desde 2007, faltavam ainda alguns indexadores estratégicos das áreas do escopo da revista. Assim, em 2013 após atender os critérios para aceitação, foi solicitado a entrada nas bases PubMed e PubMed Central, em que posteriormente ocorreu a indexação da revista (Figura 2), PubMed Central Canadá, UK PubMed Central, Depot, SpringerLink, Springer Images/Author Mapper, CrossRef, Elsevier/ELSAMS,
Quertle, Scirus, European Patent Office (EPO), OhioLINK, SIMID, CISTI (Canada Institute for STI), Proquest, GALE e WebCite/Webcitation. Além disso, a revista já era indexada nas seguintes bases de dados: Biological Abstracts, BIOSIS, CABI, CAS, CSA, DOAJ, EBSCO, Embase, Global Health, e Zoological Record. Essas novas indexações aumentaram a visibilidade do periódico.

Figura 2. Indexação no PubMed Central a partir de 2013.

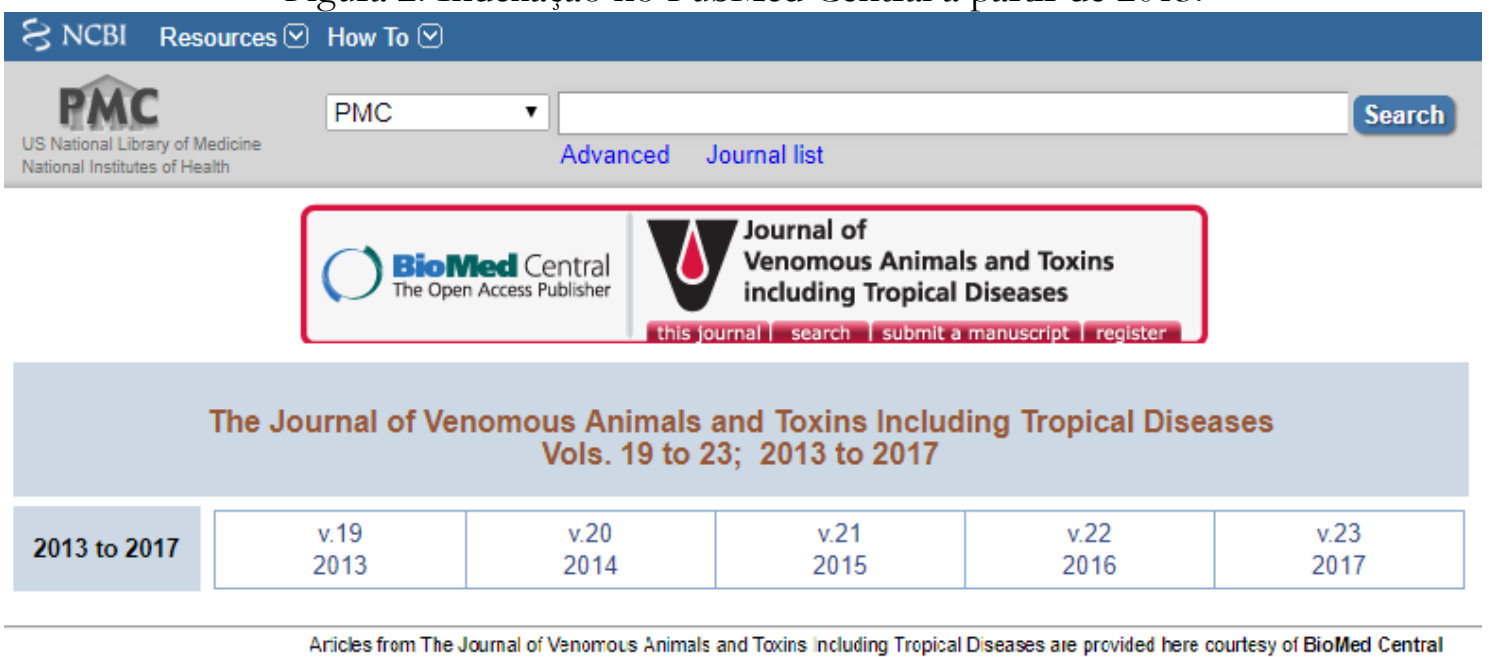

Fonte: PubMed Central https://www.ncbi.nlm.nih.gov/pmc/journals/2145/

\subsection{Reavaliar o corpo editorial}

O corpo editorial foi totalmente reavaliado convidando-se cientistas de renome nacional e internacional. Além disso, adotou-se a estratégia de que todo colaborador deve publicar na revista pelo menos um artigo de impacto por ano. Essa medida, além de aumentar o número de submissões ainda contribuiu para dar qualidade aos conteúdos publicados. Os editores associados passaram a ter um papel relevante na revista e serão trocados periodicamente se necessário. Além de colaborar com a submissão de manuscritos, eles também são responsáveis por ajudar o editor-chefe a convidar novos colaboradores e a elaborar as séries especiais e temáticas. Hoje o corpo editorial do JVATiTD é assim constituído: 14 pesquisadores brasileiros e 16 estrangeiros. Os últimos são oriundos de: Cuba (1), Egito (1), China (1), Venezuela (1),
Argentina (1), Algéria (1), Nigéria (1), Reino Unido (1), França (3), México (1), Turquia (1), Polônia (1), Tailândia (1) e Bélgica (1). Esse novo grupo de pesquisadores contribuiu para atrair bons manuscritos e melhorar a qualidade dos artigos publicados.

\subsection{Priorizar qualidade}

Para se priorizar a qualidade há necessidade de uma avaliação rigorosa na "porta de entrada", ou seja, assim que o manuscrito é submetido, o editor-chefe deverá avaliar se vale a pena publicar ou não. Algumas perguntas são estratégicas neste momento: esse artigo está no escopo da revista? Ele está dentro das normas? Será citado? É inovador? É atual? Onde estão as novidades? Se uma dessas perguntas for negativa, o manuscrito deve ser rejeitado da porta. Com isso, haverá um volume menor de artigos para publicar e menos serviço para o 
corpo editorial e demais colaboradores. Nesse momento, é necessário ter coragem, ser focado e priorizar apenas a qualidade.

\subsection{Cortar supérfluos}

O editor-chefe precisa ter coragem de "cortar na carne". Evitar editoriais desnecessários, cartas, resumos de teses, de congressos e artigos de pouco interesse. É imprescindível rever o hábito de se publicar um editorial a cada novo número da revista. Pois esse tipo de publicação aumenta o denominador da equação e, portanto, contribui para diminuir o fator de impacto do periódico. Dessa forma, comedimento é chave: publicar apenas o necessário e o suficiente.

\subsection{Estimular publicação em multimídia}

Os editores devem estimular os autores a incluir nos manuscritos conteúdos em vídeo e áudio. Isso gerará maior visibilidade, interesse e, consequentemente, citação. $\mathrm{O}$ vídeo 'Animated life cycle of T. cruzi in the human host" é um arquivo adicional de um dos artigos publicados no JVATiTD. Essa publicação é hoje uma das mais visitadas e citadas.

\subsection{Manter um banco de dados atualizado $^{2}$}

A revista deve ter um banco de dados atualizado e com todo conteúdo publicado desde a sua fundação. Esse banco deve ser consultado toda vez que um novo artigo for submetido. As perguntas estratégicas são as seguintes: já publicamos algo semelhante? Esse assunto deve ser publicado novamente?

\subsection{Participação dos editores em eventos da área}

O editor-chefe e os editores associados devem participar dos eventos relacionados ao escopo do periódico.

\footnotetext{
${ }^{1}$ Disponível

em: $<$ https: / / www.youtube.com/watch?v=1ais69H0li 8 >. Acesso em: 2 dez. 2017
}

Portanto, é interessante contatar previamente o presidente do congresso e oferecer a oportunidade de divulgar os melhores trabalhos. Por exemplo, sugerir que os três melhores estudos serão publicados na revista sem ônus. Inserir panfletos da revista na pasta dos congressistas também é uma opção. Visitar a sessão de pôsteres e conversar com os autores é outra forma de prospectar possíveis colaboradores, assim como convidar palestrantes para submeter bons manuscritos. Deve-se, portanto, construir uma network sólida.

\subsection{Participação dos editores em grupos de pesquisa}

Os editores são incentivados a fazer pesquisa de fronteira e a participar de grupos consolidados. Nesse caso, quando eles submetem manuscritos para publicação em outras revistas é possível citar artigos da sua revista. Esse tipo de citação contribuirá para aumentar a visibilidade, o prestígio e consequentemente o fator de impacto.

\subsection{Estimular os editores a dar parecer para outras revistas}

Os colaboradores devem ser pareceristas de boas revistas indexadas. Pois, quando avaliarem artigos de outros periódicos, poderão sugerir a consulta de bons artigos publicados em sua revista. A aceitação dessas sugestões ficará sempre a critério dos autores do manuscrito.

\subsection{Publicar séries temáticas e especiais}

As séries temáticas e especiais são um conjunto de publicações coordenadas por um editor convidado de renome internacional, da mais alta competência acadêmica. Esse especialista irá prospectar autores internacionais para elaborar manuscritos de elevada qualidade dentro de uma temática previamente definida. Nestes últimos anos o JVATiTD finalizou e publicou cinco séries,

\footnotetext{
${ }^{2}$ Disponível $\mathrm{em}:<$ http://www.jvat.org.br/full/jvat full.htm $>$. Acesso em: 2 dez. 2017
} 
com trabalhos na fronteira do conhecimento, e sobretudo citáveis pela comunidade cientifica mundial.

\subsection{Evolução da homepage do JVATiTD}

As Figuras 3 e 4, mostram momentos distintos dos websites do JVATiTD, sendo a primeira em 2013 e a segunda em 2017.

Figura 3. Website da JVATiTD em 2013.

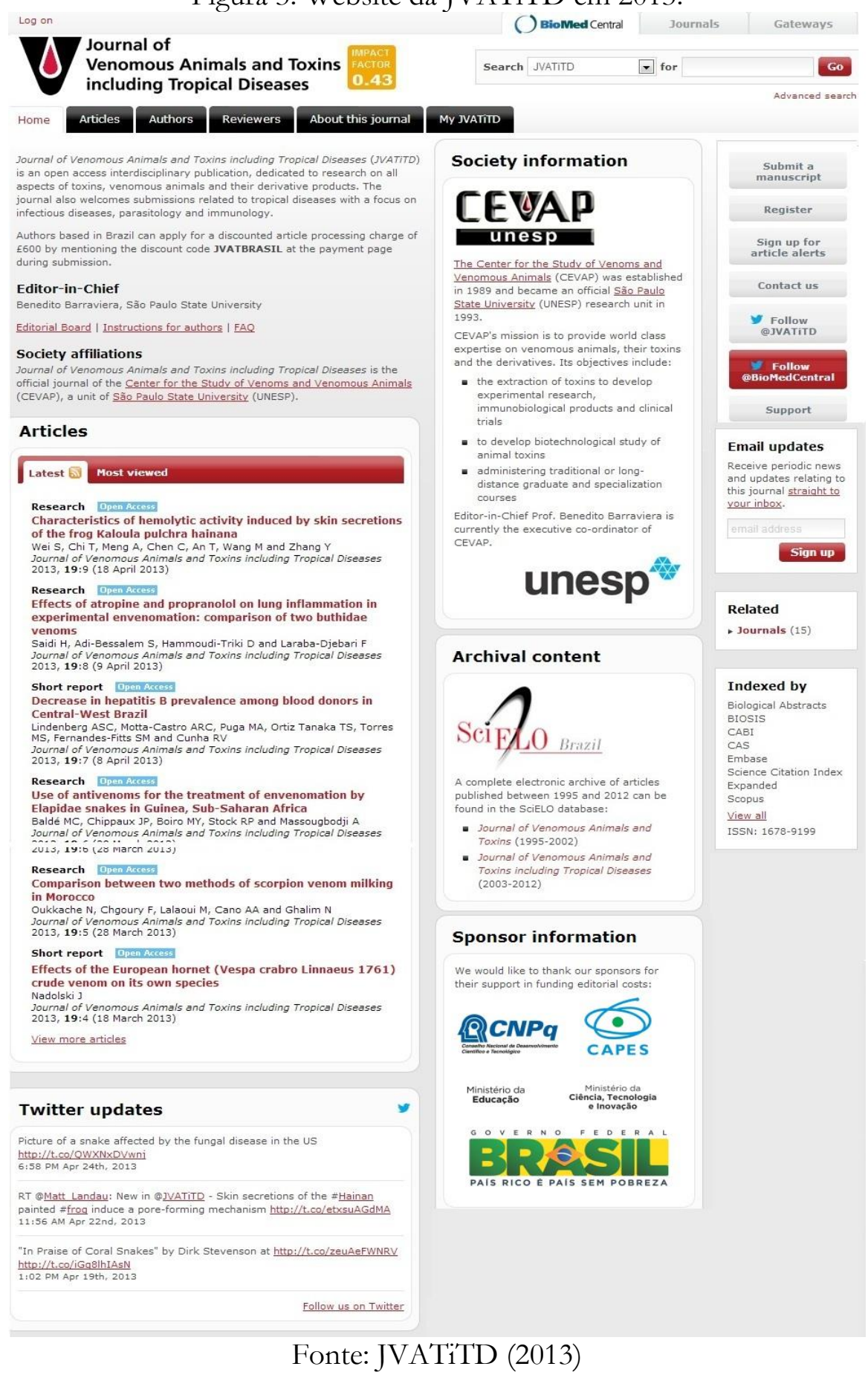


Figura 4. JVATiTD em 2017

$\triangle B M C$

Journal of Venomous Animals and Toxins including Tropical Diseases

\begin{tabular}{|l|l|l|l|}
\hline Home About Articles Collections Submission Guidelines & Submit a manuscript \\
\hline Search articles within this journal
\end{tabular}

Where do you prefer to publish? Tell us in our 10 minute survey, Charitable donation for first 1000 responses!

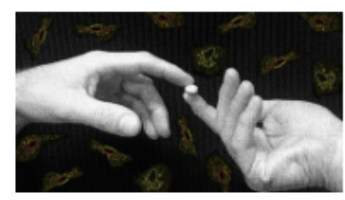

Call for Papers: Novel hit and lead compounds against neglected protozoan diseases

JVATITD

Edited by Andre G. Tempone and Erika G. Pinto

This collection aims to build bridges between novel hit or lead compounds and new alternative therapies for neglected protozoan diseases (including malaria). We welcome contributions describing the in vitro and/or in vivo activity of antiprotozoan compounds isolated from natural products and synthetic compounds.

The proposed deadline for submissions is March 20, 2018.

Editorial Board

Sign up to article alerts

FOLLOW

(†)

2016 Journal Metrics

\begin{tabular}{l|l} 
Articles \\
$\mid$ Recent & Most accessed \\
\hline Most accessed articles RSS B
\end{tabular}

RESEARCH | 12 December 2017

Most accessed articles RSS ה

Benznidazole affects expression of Th1, Th17 and

Treg cytokines during acute experimental

Trypanosoma cruzi infection

Mariana Gatto, Larissa Ragozo Cardoso Oliveira, Fernanda De Nuzzi Dias, João Pessoa Araújo Júnior, Carlos Roberto Gonçalves Lima, Eliana

Peresi Lordelo, Rodrigo Mattos dos Santos and Cilmery Suemi

Kurokawa

RESEARCH | 28 November 2017

Crotalus durissus terrificus crotapotin naturally

displays preferred positions for amino acid substitutions

Laudicéia Alves de Oliveira, Rui Seabra Ferreira Jr, Benedito Barraviera, Francilene Capel Tavares de Carvalho, Luciana Curtolo de Barros, Lucilene Delazari dos Santos and Daniel Carvalho Pimenta

REVIEW | 26 October 2017

The modular nature of bradykinin-potentiating peptides isolated from snake venoms

Juliana Mozer Sciani and Daniel Carvalho Pimenta

REVIEW | 18 October 2017

It is time for top-down venomics

Rafael D. Melani, Fabio C. S. Nogueira and Gilberto B. Domont

RESEARCH | 3 October 2017

Preliminary molecular characterization of a

proinflammatory and nociceptive molecule from

the Echinometra lucunter spines extracts

Juliana Mozer Sciani, Bianca Zychar, Luis Roberto Gonçalves, Renata

Giorgi, Thiago Nogueira and Daniel Carvalho Pimenta

\section{Aims and scope}

Journal of Venomous Animais and Toxins including Tropical

Diseoses (JVATITD) is an open access interdisciplinary

publication, dedicated to research on all aspects of toxins,

venomous animals and their derivative products. The journa! also welcomes submissions related to tropical diseases with a focus on infectious diseases, parasitology and immunology. Read more about the journal scope.

Speed

47 days from submission to

first decision

12 days from acceptance to

publication

Citation Impact

1,447 - 2 -year Impact Factor

1.129 - -year Impact Factor

\section{Article collections}

Call for Papers - Novel hit and lead compounds against neglected protozoan diseases

Edited by Andre G. Tempone and Erika G. Pinto

Hyphenated mass spectrometry strategies as tools for unveiling_peptide toxins with potential therapeutic application

Edited by Daniel Pimenta and Philippe Bulet

Highlights in Toxinology: Challenges and Progress Edited by Benedito Barraviera and Maria Elena de Lima

Strategies for management of snakebites in Africa

Edited by Benedito Barraviera

Animal toxins: Exploring novel bioactive compounds from

toads, snakes and scorpions

Edited by Benedito Barraviera

Highlights in arthropod venoms: Potential applications in

Usage

medicine and biotechnology.

Edited by Maria Elena de Lima, Yong-Hua Ji and Maria Stankiewicz

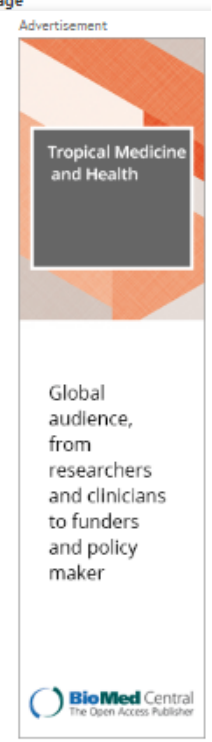




\section{Institutional affiliation \\ CEVAP -unesp- \\ The Center for the Study of Veroms and Venomous Animals (Cevap) was established in 1989 and became an officiat Szäo Paule State University, \\ (Uhesp) research unit in 1993. Cevap's mission is to provide worid class expertise on venomous animals, their toxins and the derivatives, its objectives include: \\ - the extraction of toxins to deve op experimental research, immunobiological products and clinical trials \\ - to deveiop biotechnological study of animal toxins \\ - administering traditional or long-distance graduate and specialization courses}

\section{Sponsor information}

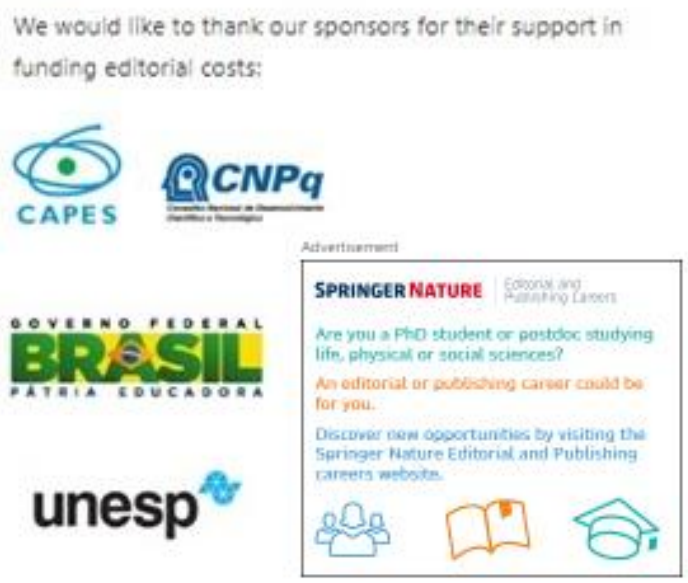

\section{Archival content}

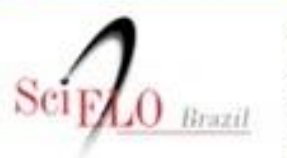

A complete e ectronic archive of articies published between 1995 and 2012 can be found in the SciElo database:

- Journal of Venomous Animais and Toxins [1995-20021.

- Leurna of Venomous Animals and Toxins including Iropical Diseases (2003-2012).

\section{Editor's quote}

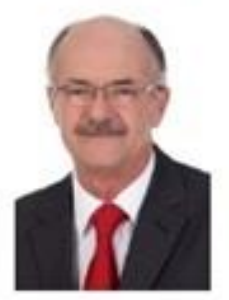

Tropical Diseases and Toxinology are neglected areas in intemational science. Therefore, we must have research models that are efficient, cheaper and appli cable to our patients. At Cevap, we believe that natural toxins comprise fascinating aternative models that are innovating the development of new drugs to treat animal and human diseases.

Dr. Benedito Barraviera is a researcher at the Center for the Study of Venoms and Venomous Animais (Cevap) and full professor of the Department of Tropical Diseases of Botucatu Medical $5 \mathrm{chool}$, both at Sảo Paulo State University (Unesp), Brazil.

\section{Latest Tweets}
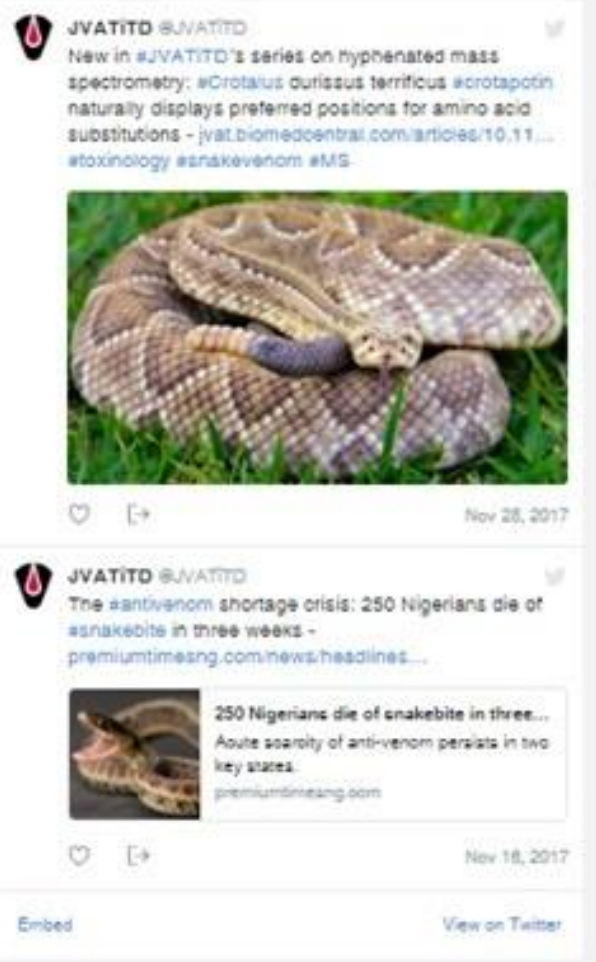

Fonte: JVATiTD (2017)

\section{RESULTADOS PRELIMINARES}

As ações implementadas no início de 2013 já deram alguns resultados que puderam ser observados a partir de 2015 e confirmados em 2017.
Em 2015 o periódico foi reclassificado pelo Programa WebQualis da Coordenação de Aperfeiçoamento de Pessoal de Nível Superior (Capes) nos seguintes estratos, a saber: B1: Medicina Veterinária, Zootecnia/Recursos Pesqueiros; B2: 
Medicina I, Medicina II, Odontologia, Saúde Coletiva, Farmácia; B3: Ciências Biológicas I, Ciências Biológicas II, Ciências Biológicas III.

Com relação ao prazo decorrido entre a submissão e a aceitação, foi possível observar que em 2016 esse tempo foi de 104 dias. Essa análise permite concluir que a velocidade da publicação aumentou significativamente nos últimos anos. Hoje o tempo decorrido entre a submissão e a publicação é semelhante aos periódicos de maior impacto mundial.

Com relação ao impacto das citações, notou-se um aumento tanto na base WoS quanto Scopus (Scimago). As Figuras 5 e 6 confirmam estes resultados.

Figura 5. Evolução do fator de impacto no WoS (JCR) entre 2007 e 2016.

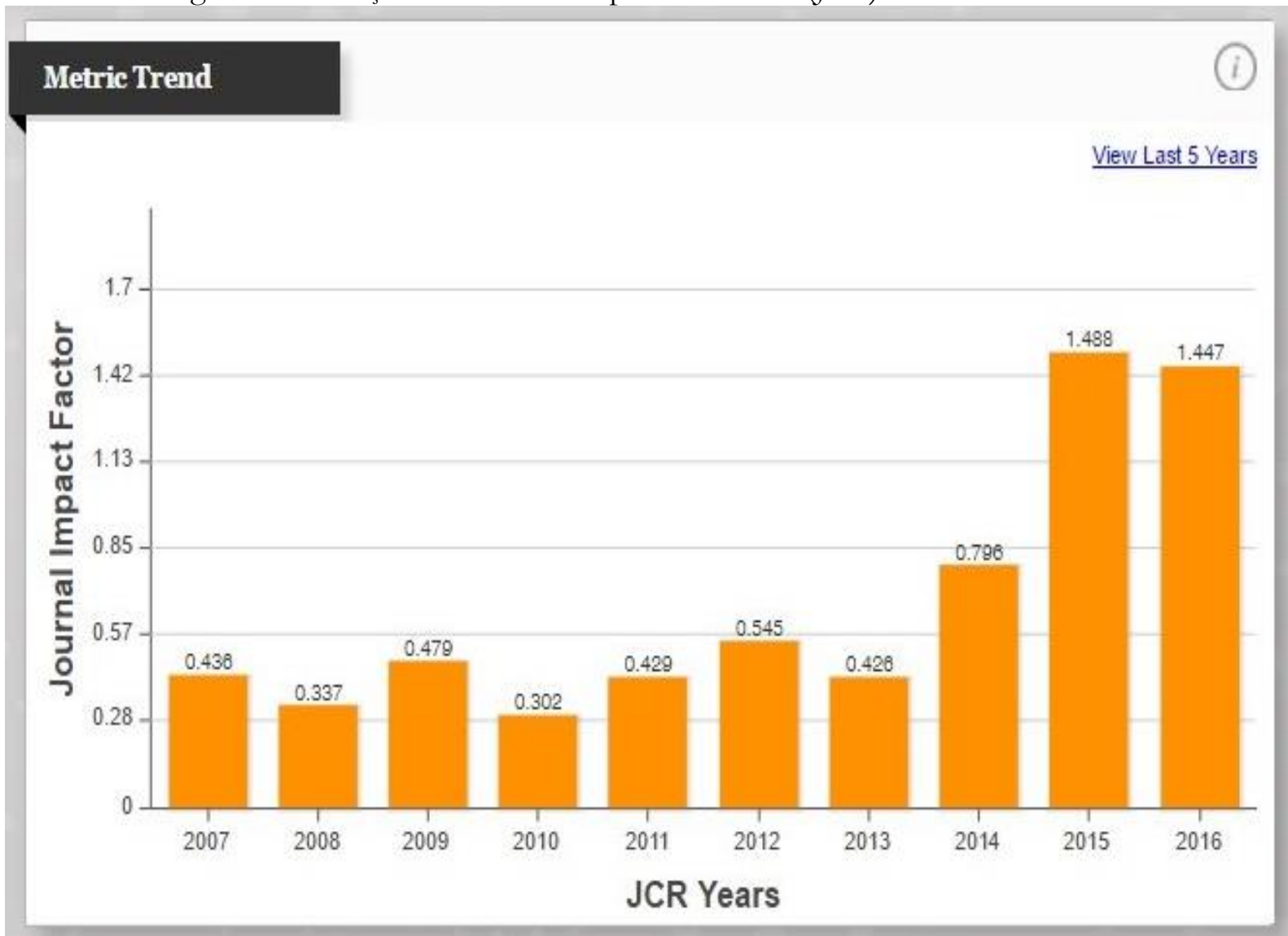

Fonte: JCR (2016) 
Figura 6. Evolução do Cites/Doc no Scopus (Scimago) entre 2007 e 2016.

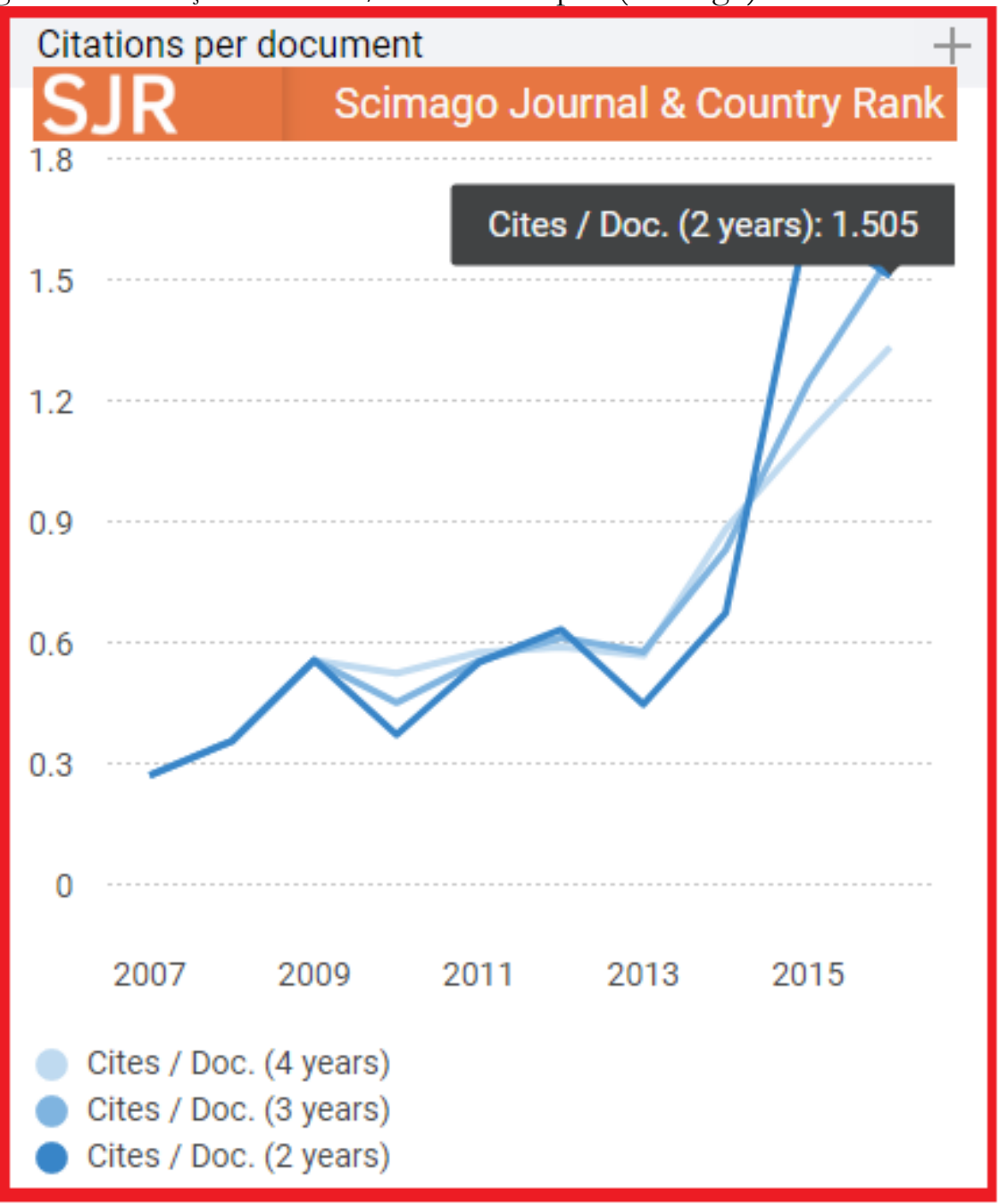

Fonte: Scimago (2015)

\section{CONCLUSÕES}

A parceria com a BioMed Central Springer-Nature foi estratégica, pois em 2017 atingimos impacto de citação acima de 1.0 tanto no WoS (JCR $=1.447)$, quanto no Scopus (Scimago $=1.505$ ). Isso certamente deverá atrair a submissão de bons manuscritos, aumentar o prestígio, a visibilidade mundial e o aumento do número de citações. Como consequência direta o FI deverá aumentar nos anos vindouros.

\section{AGRADECIMENTOS}

Nosso especial agradecimento aos pioneiros Heloisa Maria Pardini Toledo (revisora de idioma), Maria Fernanda Sarmento e Souza e Paulo Rubens Oliveira (técnicos de informática e editoração) que acreditaram e apoiaram durante anos a implantação deste novo paradigma. Agradecemos também a Karina Luiz Chamma, Ana Silvia Sartori Barraviera Seabra Ferreira, Marco Antonio Nogueira Duarte, Claudio Pires Martins e os demais bolsistas. À Universidade Estadual Paulista "Júlio de Mesquita Filho" (UNESP) e ao CEVAP por abrigar e apoiar a publicação desde 1995. À Mariana Rocha Biojone, Managing Director of Springer Brasil, por apoiar integralmente a parceria com a BioMed Central.

\section{APOIO}

A partir de 2005 ininterruptamente até o presente momento as agências de fomento Capes e Conselho Nacional de 
Desenvolvimento Científico e Tecnológico $(\mathrm{CNPq})$ apoiaram a revista com recursos de custeio por meio dos editais anuais de editoração. A partir de 2007 o programa de apoio às publicações científicas da
Universidade Estadual Paulista em Franca (UNESP) mantido pela Pró-Reitoria de Pesquisa também tem apoiado com recursos de custeio, capital e bolsas.

\title{
HOW TO INCREASE THE IMPACT FACTOR IN WEB OF SCIENCE (WOS) AND SCOPUS (SCIMAGO) DATABASES: ACTIONS IMPLEMENTED BY JOURNAL OF VENOMOUS ANIMALS AND TOXINS INCLUDING TROPICAL DISEASES
}

\begin{abstract}
The Journal of Venomous Animals and Toxins including Tropical Diseases (JVATiTD) was indexed in the Web of Science (WoS) and Scopus (Scimago) databases in 2006. Between 2007 and 2012, the Impact Factor (IF) remained between 0.30 and 0.55. In order to improve it, in 2013 a partnership with BioMed Central Springer-Nature was established and a series of actions were taken aiming to reach an IF of 2.0 in five years. The actions included: to publish in continuous flow, to look for new strategic indexers, to evaluate the editorial board, to prioritize quality content, to cut uncited content, to stimulate multimedia publishing, to keep an updated database, and to publish thematic and special series. Associate editors were asked to participate in meetings and join renowned research groups, as well as work as peer reviewers for other journals. Nowadays, we can say that the new partnership was strategic, for in 2017 our citation impact was above 1.0 in both Web of Science (WoS) and Scopus (Scimago) databases. This will certainly attract submission of good manuscripts, improve the visibility and increase the number of citations. As a direct consequence, the IF will increase in a near future.
\end{abstract}

Keywords

Impact factor. Web of Science. Scopus. Scientific publishing Artigo recebido em 05/02/2018 e aceito para publicação em 19/02/2018

\section{REFERÊNCIAS}

BARRAVIERA, Benedito. Journal of Venomous Animals and Toxins including Tropical Diseases. J Venom Anim Toxins incl Trop Dis. Botucatu, v. 19, artigo n. 1, BCM, 2013. http://dx.doi.org/10.1186/1678-9199-19-1.

BARRAVIERA, Benedito. Journal of Venomous Animals and Toxins including Tropical Diseases: the first Brazilian electronic scientific publication turns 20 years old. J Venom Anim Toxins incl Trop Dis. Botucatu, v. 19, artigo n. 52, BCM, n. 1, dez. 2015. http://dx.doi.org/10.1186/s40409015-0050-7.

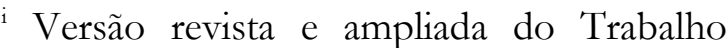
"Como aumentar o fator de impacto nas bases Web of Science (WoS) e Scopus (Scimago): ações implementadas pelo "Journal of Venomous Animals and Toxins including Tropical Diseases" apresentado no evento ABEC MEETING, 6-9, novembro, Curitiba, PR, 2017
}

350 years of Scientific Publishing, JVATiTD, 2015. Video Online (8:44 min), son,. Color. Disponível em: $<$ https://www.youtube.com/watch?v=lhdP 3P4BrRU>. Acesso em: 25 dez. 2017.

INTERNATIONAL COMMITTEE OF MEDICAL JOURNAL EDITORS. International Committee of Medical Journal Editors. Disponível em: $<$ http://www.icmje.org/z. Acesso em: 27 dez. 2017. 